\title{
WET INTEGRATED FLUE GAS CLEANING
}

\author{
Igor Volchyn ${ }^{1}$, Vladyslav Rashchepkin ${ }^{2}$, Andrii Yasynetskyi ${ }^{3}$, Wlodziemierz Przybylski ${ }^{4}$ \\ 1. Coal Energy Technology Institute, The National Academy of Sciences of Ukraine, \\ 19, Andriyvska str., Kyiv, 04070, UKRAINE, E-mail: volchyn@ gmail.com \\ 2. Coal Energy Technology Institute, The National Academy of Sciences of Ukraine, \\ 19, Andriyvska str., Kyiv, 04070, UKRAINE, E-mail: slava003@ukr.net \\ 3. Coal Energy Technology Institute, The National Academy of Sciences of Ukraine, \\ 19, Andriyvska str., Kyiv, 04070, UKRAINE, E-mail: aoyasin@gmail.comt
}

4. Dagas Sp. z o.o., ul. Gosnewska, 46, 05-660, Warka, POLAND, E-mail: wlodzimierz.przybylski@ dagas.pl

\begin{abstract}
A wet method for flue gas cleaning from ash and sulfur dioxide based on a wet venturi scrubber has been proposed An increase in the specific consumption of irrigation water in the Venturi tube of $0.7 \mathrm{~kg} / \mathrm{m} 3$ and higher will allow reaching an output dust concentration below $20 \mathrm{mg} / \mathrm{m}^{3}$, while reducing the energy consumption of flue gas for droplet evaporation and fresh water consumption. The use of ammonia in wet desulfurization technology will allow the use of an existing wet scrubber while observing the $\mathrm{SO}_{2}$ limit concentration of $200 \mathrm{mg} / \mathrm{m}^{3}$.
\end{abstract}

Keywords - wet scrubber Venturi, flue gas, dust removal, wet ammonium desulfurization, ammonia sulfate.

\section{Introduction}

The Association Agreement between Ukraine and the European Union in 2014 includes an obligation for our country to comply with the requirements of the Directive 2010/75/EU on industrial emissions [1]. This is especially true of thermal power plants, which are among the main sources of pollutants of the environment. The actual level of dust concentrations in the flue gases of TPPs of Ukraine is in the range of $400-1500 \mathrm{mg} / \mathrm{m}^{3}$, depending on the type of ash collector used. The concentration of sulfur dioxide is determined by the sulfur content in the fuel and is in the range of $2500-6500 \mathrm{mg} / \mathrm{m}^{3}$. In November 2017, the Order of the Cabinet of Ministers of Ukraine approved the National Plan of Emission Reduction from large combustion plants [2], which provides for the stading implementation of the requirements of Directive 2010/75/EU. After December 31, 2018, on existing combustion plants, the final concentration of dust should be no higher than $20 \mathrm{mg} / \mathrm{m}^{3}$, and the emission limit value of sulfur dioxide in dry flue gases will be $200 \mathrm{mg} / \mathrm{m}^{3}$. To ensure such high requirements, the efficiency of the dust cleaning system should be at least $99.85 \%$ with the initial dust content of the flue gas (DG) stream $30 \mathrm{~g} / \mathrm{m}^{3}$, and to reduce the $\mathrm{SO}_{2}$ emission, it is necessary to ensure the binding of sulfur dioxide with an efficiency higher than $96 \%$.

In Ukraine, a significant part of coal-fired boilers (up to $30 \%$ by thermal capacity) of thermal power plants and combined heat and power plants are equipped with wet scrubbers with Venturi tubes for flue gas cleaning. In Fig. 1 is a schematic of a wet Venturi scrubber. The flue gas after the boiler air preheater passes through the Venturi tube. In the Venturi nozzle, water drops form, which are the coagulation centers of dust particles. After the Venturi tube, the flue gas flow and droplets of water and dust slurry tangentially enter the bottom of the wet scrubber. Due to the centrifugal force of the suspension drops will be deposited on the wall of the scrubber, on which to prevent drip entrainment with a water supply, a stable water film is provided. The ash pulp is discharged from the low part of the scrubber.

The technology of particulate matter removal in wet scrubbing is included in the European list of the Best Available Techniques [3]. These ash collectors also partially reduce sulfur dioxide emissions (up to $10 \%$ ) due to the solubility of $\mathrm{SO}_{2}$ in water and the presence of alkaline earth components in the ash. 


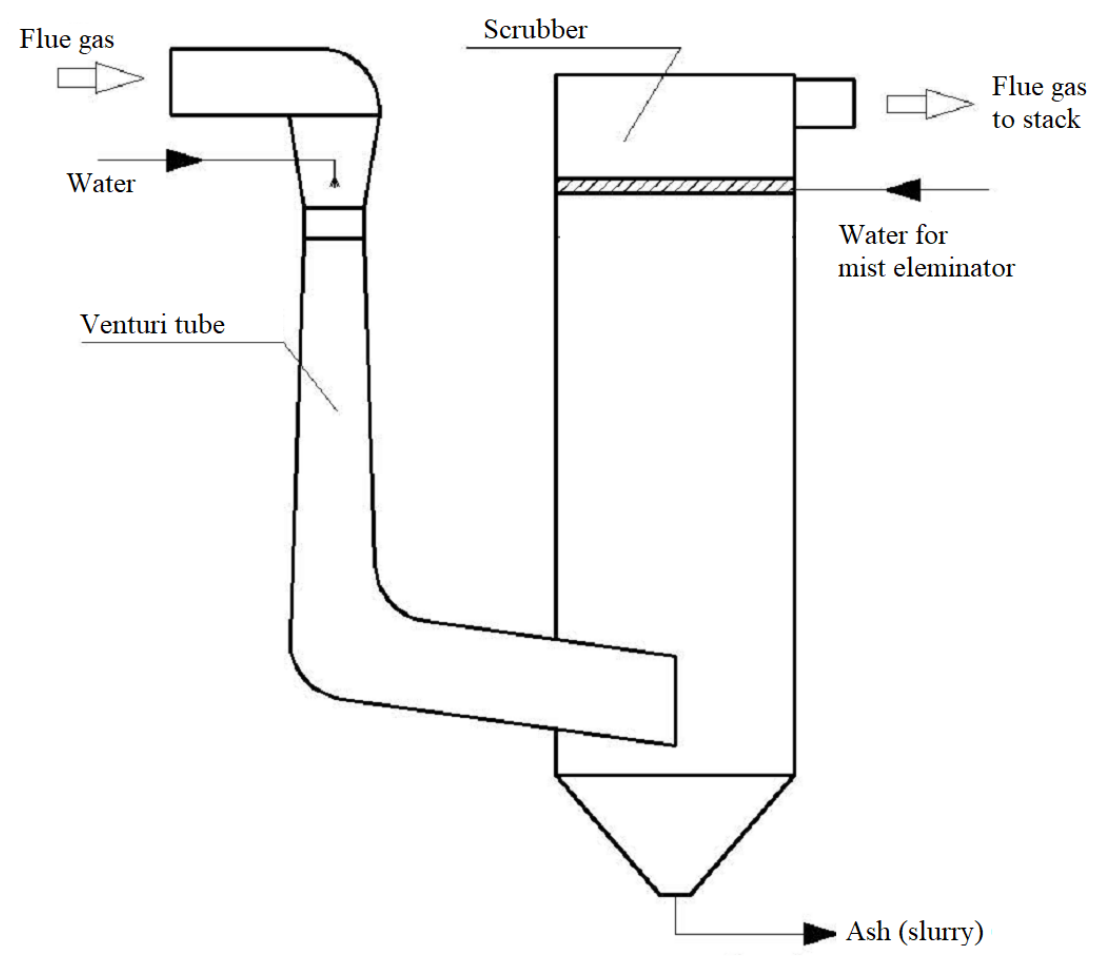

Fig. 1 - Wet scrubber with Venturi tube

Under the conditions of the dense layout of equipment of existing TPPs and CHPs of Ukraine, there is often no room for placing new ash collectors and desulfurization systems. One of the solutions to this problem may be the modernization of existing wet Venturi scrubbers to the apparatus for complexly cleaning of flue gas from dust and sulfur dioxide, according to the requirements of Directive 2010/75/EU.

\section{Material and Methods}

Optimization of the structural parameters of wet scrubbers has limited possibilities for a significant increase in dust collection efficiency. A significant improvement in dust collection in wet scrubbers can be achieved mainly only by increasing the water consumption for irrigation of the Venturi pipes.

Traditionally, the specific consumption of irrigating water in the Venturi pipe was limited to $200 \mathrm{~g} / \mathrm{m}^{3}$ by the condition that the flue gas reaches a dew point and the danger of corrosion of equipment located downstream. In addition to dust cleaning, the modernization of wet Venturi scrubber involves the introduction of desulfurization systems, the most effective of which are wet-type plants $[3,4]$.

There is a practical experience of using intensive irrigation regimes of scrubbers with Venturi pipes [5]: at boiler No. 12 of the Togliatti CHP in 2007, modernization was carried out to transfer wet ash collectors to intensive irrigation, which increased the efficiency of ash collection to $99.5 \%$ due to an increase in the irrigation density of the Venturi coagulators by 3.5 times. However, it also required heating of the purified flue gases by no less than $10{ }^{\circ} \mathrm{C}$.

An increase in the flow rate of the irrigating water will influence the working efficiency and the selection of the operating parameters of the wet ash collector. An increase in the flow rate of irrigating fluid will affect the dynamics of evaporation of droplets in an environment with varying moisture content. From the diameter of the droplets depends on the efficiency of the capture of particles of fly ash droplets in the Venturi tube. An increase in the irrigation consumption will lead to an increase in the hydrodynamic resistance of the wet ash collector, which entails the need to increase the performance of ID fan. 
Estimation of the efficiency of trapping solid particles in a wet Venturi scrubber can be performed on the basis of a mathematical model of particle deposition on water droplets in a Venturi tube [6,7], the adequacy of which is confirmed by experimental data $[5,8,9]$, using the formula $^{\wedge}$

$$
\eta=1-\exp \left(-\frac{3}{2} \frac{q_{w}}{D_{d} \cdot \rho_{l}} \cdot \int_{0}^{L} \eta_{\Sigma}(x) \cdot\left|\frac{v_{p}(x)-v_{d}(x)}{v_{d}(x)}\right| d x\right),
$$

where $q_{w}$ - irrigation density of gas-dust flow, $\mathrm{kg} / \mathrm{m}^{3} ; \eta_{\Sigma}-$ precipitation coefficient of solid particles with a diameter $d_{p}$ on spherical droplets with a diameter $D_{d} ; \rho_{l}$ - water density, $\mathrm{kg} / \mathrm{m}^{3}$; $v_{p}$ - velocity of ash particle with diameter $d_{p}, \mathrm{~m} / \mathrm{s} ; v_{d}$ - velocity of drop with diameter $D_{d}, \mathrm{~m} / \mathrm{s} ; L$ - Venturi tube length, $\mathrm{m} ; x$ - coordinate along the Venturi tube axis, $\mathrm{m}$.

To remove sulfur dioxide, it is proposed to apply, on the basis of the existing wet scrubber, a wet ammonium sulfate technology [3, 10], which has a high desulfurization efficiency, obtained as a by-product of ammonium sulfate (mineral fertilizer).

\section{Results and discussion}

The results of the calculation of the efficiency of cleaning flue gases from fly ash for different sizes of dust particles and different consumption of irrigating water in the Venturi tube are presented in Figure 2.

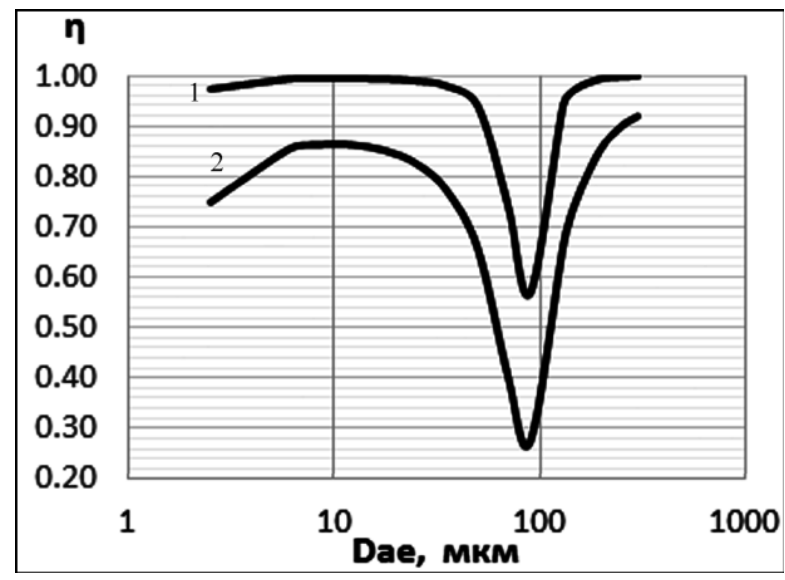

Fig. 2 - Fractional efficiency $\eta$ of flue gas cleaning in the Venturi with $q_{w}=0.42 \mathrm{~kg} / \mathrm{m}^{3}$ (curve 1) and $q_{w}=0.16 \mathrm{~kg} / \mathrm{m}^{3}$ (curve 2).

Curve (2) shows the efficiency of dust collection by droplets of $150 \mu \mathrm{m}$ in diameter in the Venturi tube at an irrigation density of $q_{w}=160 \mathrm{~g} / \mathrm{m}^{3}$. Curve (1) corresponds to dust collection efficiency with the same drops at $q_{w}=420 \mathrm{~g} / \mathrm{m}^{3}$. With an increase in irrigation consumption, the efficiency of trapping dust ranging in size from units to tens of microns is high and approaching unity (100\%). The dips in curves (1) and (2) are explained by the convergence of the values of the aerodynamic diameters of dust particles and droplets; here, $\left|\left(v_{p}-v_{d}\right) / v_{d}\right| \rightarrow 0$, and particles with droplets move in the gas stream without colliding. However, drops and particles of this size (more than $40 \mu \mathrm{m}$ ) are effectively captured further downstream in the scrubber droplet separator [6]. The main task is to trap small particles in the Venturi tube; these are mainly PM10 and PM2.5 particles, which are poorly captured by most ash collectors, with the exception of fabric filters. As follows from Fig. 2, the most effective particles of fly ash of this class can be captured in the Venturi tube with drops at an irrigation density of more than $400 \mathrm{~g} / \mathrm{m}^{3}$.

The dynamics of the main thermophysical parameters of a heterogeneous flow in an environment with varying moisture content was studied. In this case, the effect of droplet size on efficiency was considered. Calculations showed that droplet sizes in Venturi scrubbers to achieve an acceptable degree of dust cleaning should fall in the range of diameters: $70 \mu \mathrm{m}<D_{d}<300 \mu \mathrm{m}$ [11]. However, even in this range, the characteristic droplet size should be distinguished, 
according to which, according to the data of mathematical and engineering calculations, when designing wet Venturi scrubbers, which is also confirmed by the test results of industrial ash collecting plants with Venturi pipes at a number of TPPs, the highest ash particles are observed. These are drops with a diameter of about $150 \mu \mathrm{m}$. Therefore, it is preferable that the maximum distribution of droplets in size, formed by the nozzles that irrigate the scrubber, falls on drops of such diameter. Drops of this size under the same conditions evaporate less than, for example, droplets with a diameter of less than 50-70 $\mu \mathrm{m}$, which does not require corrections to the equations of their motion in gas as a result of changes in the size of droplets during their evaporation. An important conclusion from the comparison of the calculation results for cases of moderate and increased irrigation water flow is that the evaporation of droplets suppressed at high irrigation levels leads to a lower resulting moisture content of flue gas (Fig. 3)

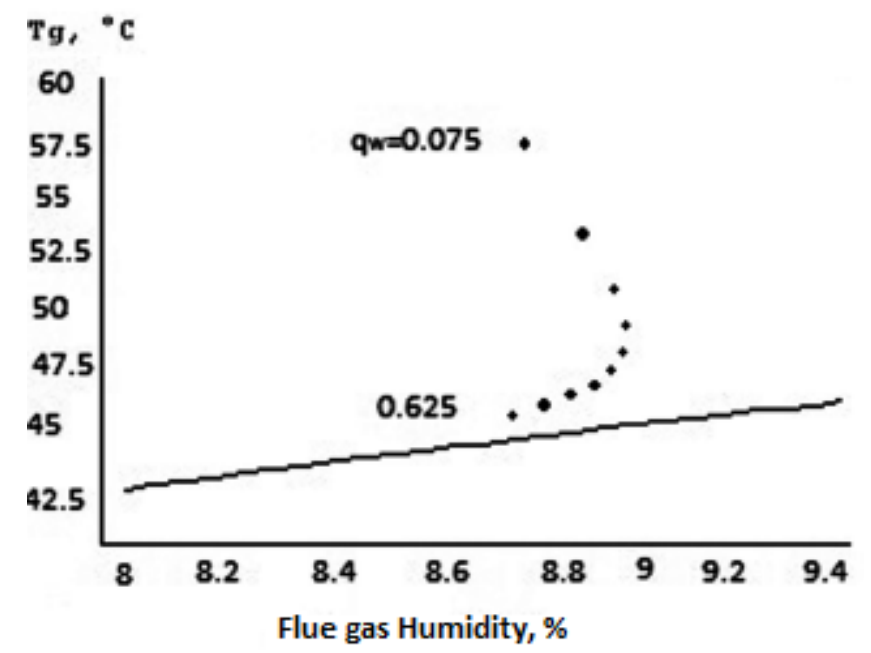

Fig. 3 - Saturation curve (solid) and points showing temperature and vapor content in flue gas at the Venturi scrubber outlet with irrigation densities $q_{w}=0.075 ; 0.185 ; 0.24 ; 0.295 ; 0.35 ; 0.405$;

$$
0.405 ; 0.46 ; 0.515 ; 0.625 ; \mathrm{kg} / \mathrm{m}^{3} \text {. }
$$

This is not an obvious conclusion at first glance, but with an increase in the amount of water injected into the Venturi tube, the humidity of the flue gases at the scrubber outlet actually decreases. This is due to the increased energy consumption by flue gases to heat the flow of droplets in the Venturi tube to the dew point with a higher irrigation density, therefore less energy will be used to evaporate the droplets [11]. Therefore, at the exit from the venturi tube, the flue gas temperature will be higher than the water temperature.

In the existing scheme of a wet venturi scrubber, pulp consisting of water (90\%) and captured ash (10\%) is transported by a pump through pipes to the ash dump. It is proposed to change the scheme for obtaining on the territory of TPPs the ownership of ash to $15 \%$ as a byproduct with its subsequent sale to consumers (Fig. 4). In the existing scheme of a wet Venturi scrubber, the pulp consisting of water (90\%) and captured ash (10\%) is transported by pumping through pipes to the ash dump. It is proposed to change the scheme for obtaining in the territory of TPPs ash ownership by up to $15 \%$ as a by-product with its further sale to consumers (Fig. 4). For this purpose, it is planned to use a hydrocyclone and a vacuum filter in order to separate the solid phase from the liquid and obtain ash as a product at the outlet. In this case, there is no need to transport the ash suspension to the ash landfill.

To remove sulfur dioxide, it is proposed to place in the wet scrubber a system of volumetric spraying of droplets of an aqueous solution of ammonia and ammonium sulfate against the flow of flue gas. The regulating grid must equalize the velocity fields after the venturi. In solution makers, ammonia forms an acid salt with sulfur dioxide by the reaction:

$$
\mathrm{NH}_{3}+\mathrm{H}_{2} \mathrm{O}+\mathrm{SO}_{2}=\mathrm{NH}_{4} \mathrm{HSO}_{3}
$$




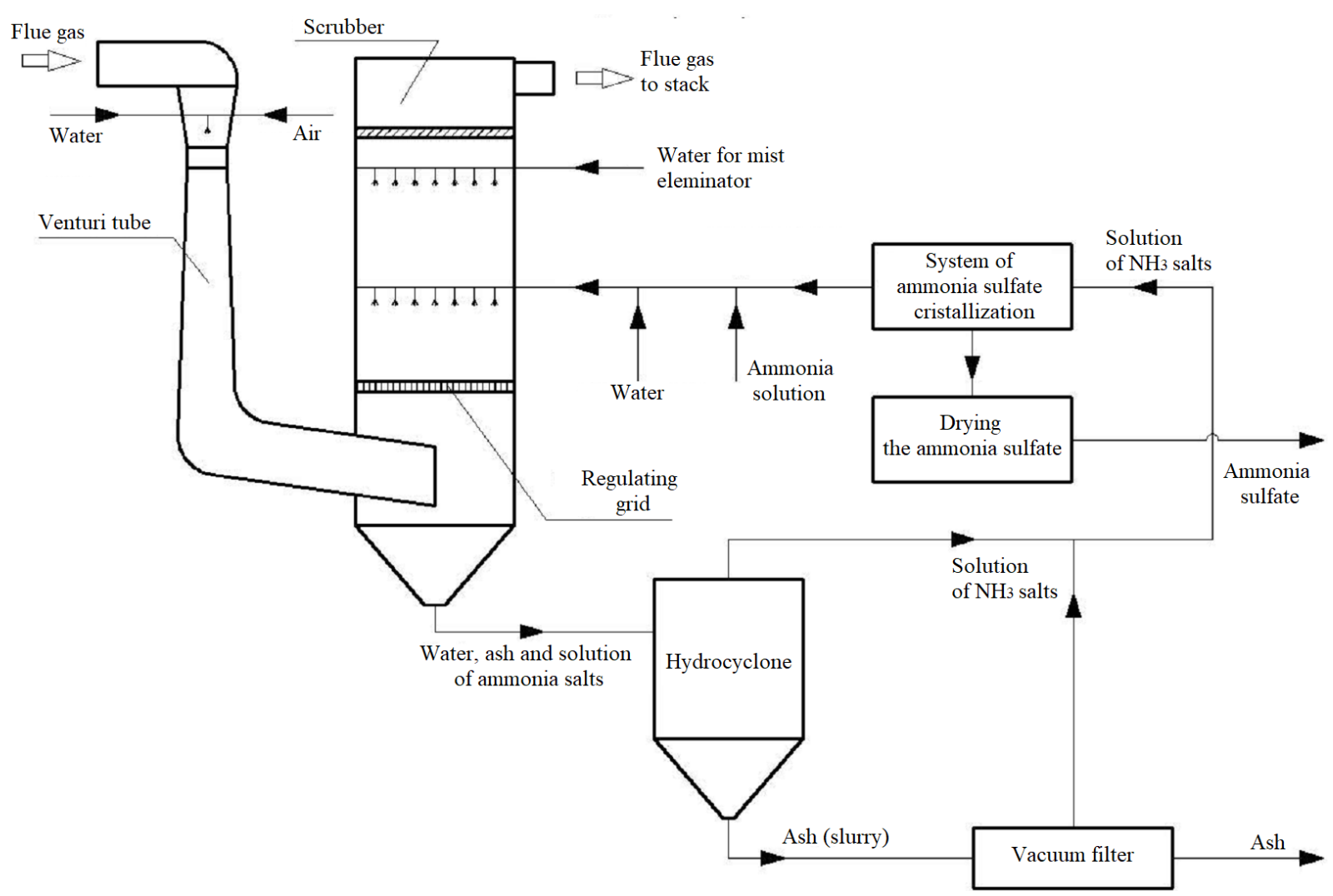

Fig. 4 - Scheme of the upgraded wet Venturi scrubber

When the droplets move to the lower part of the scrubber, the acid salt in the acidic medium will be oxidized with oxygen from the air supplied additionally with water to the Venturi nozzle to form ammonium sulfate by the reaction:

$$
2 \mathrm{NH}_{4} \mathrm{HSO}_{3}+\mathrm{O}_{2}=\left(\mathrm{NH}_{4}\right)_{2} \mathrm{SO}_{4}+\mathrm{SO}_{2}+\mathrm{H}_{2} \mathrm{O}
$$

The reactions (2) and (3) are protolytic and flow almost instantly.

Since all ammonia salts are water-soluble, after the hydrocyclone and the vacuum filter, ammonium sulfate solution will be in the liquid phase. In the system of ammonium sulfate crystallization of there will be an accumulation of its concentration in the solution until precipitation of $\left(\mathrm{NH}_{4}\right)_{2} \mathrm{SO}_{4}$ crystals. After drying, the white powder of ammonium sulfate (mineral fertilizer) will be supplied to the consumer.

The unsaturated ammonium sulfate solution together with fresh water and ammonia water is returned to the wet scrubber. The specific consumption of an aqueous solution of ammonia and ammonium sulfate in a wet scrubber is determined by the solubility of sulfur dioxide and is about $3 \mathrm{~kg} / \mathrm{m} 3$ of flue gas.

\section{Conclusions}

1. Wet Venturi scrubber can be the basis for the installation of complex cleaning of flue gases from ash and sulfur dioxide. To achieve a dust concentration below $20 \mathrm{mg} / \mathrm{m} 3$, it is proposed to increase the specific water consumption in the Venturi tube to $0.7 \mathrm{~kg} / \mathrm{m} 3$. This reduces the energy costs of evaporation of the droplets and the consumption of fresh water. The optimal drop size is $150 \mu \mathrm{m}$.

2. To reduce $\mathrm{SO}_{2}$ emissions subject to the limit value of $200 \mathrm{mg} / \mathrm{m}^{3}$ of sulfur dioxide concentration, it is proposed to use ammonium sulfate technology by spraying an ammonia solution with a flow rate of up to $3 \mathrm{~kg} / \mathrm{m}^{3}$ in a wet scrubber and obtaining an ammonium sulfate solution. 
3. A scheme has been proposed for an updated wet Venturi scrubber with a system for obtaining ash with a humidity of up to $15 \%$ and a system of obtaining the ammonium sulfate as a by-product, allowing to abandon the hydraulic ash disposal system.

\section{References}

[1] "Direceive 2010/75/EU of the European Parliament and of the Council of 24 November 2010 on industrial emissions (integrated pollution prevention and control)", OJ L 334, 17.12.2010.

[2] "On the National Emission Reduction Plan for the Large Combustion Plants". Decision of the Cabinet of Ministers of Ukraine. No. 796-p. dated 8 Nov., 2017. - Available: http://zakon3.rada.gov.ua/laws/show/796-2017-p. (Ukr). [Accepted Apr. 11, 2019]

[3] "Best Available Techniques (BAT) Reference Document for Large Combustion Plants". Joint Research Centre (JRC), Spain. 2017. 986 p. Available: - http: //eippcb.jrc.ec.europa.eu /reference/BREF/LCP/JRC107769_LCP_bref2017.pdf. [Accepted Apr. 11, 2019]

[4] Volchyn I.A. "Perspektyvy vprovadzhennia chystykh vuhilnykh tekhnolohij v enerhetyku Ukrainy" ["Prospects for the introduction of clean coal technologies in the energy sector of Ukraine"] / I.A. Volchyn, N.I. Dunayevska, L.S. Haponych, M.V. Cherniavskyi, O.I. Topal, Ya.I. Zasiadko. - K.: GNOZIS. - 2013. - 310 s. (Ukr).

[5] Anichkov S.N., Giniyatullin R.I., Zykov A.M. "Povyshenije effektivnosti ulavlivanija letuchej zoly v apparatakh mokrogo zoloulavlivanija" ["Increase of the efficiency of fly ash capture in devices of wet ash collecting"]. Elektricheskiye stantsii [Electrical plants]. 2009. No. 8. pp. 59-62.(Rus.)

[6] Volchyn I.A., Raschepkin V.A. "Matematicheskoje modelirovanije protsessov koaguljatsii chastits letuchej zoly s kapliami zhydkosti v trubakh Venturi skrubberov TES". ["Mathematical modeling of the processes of coagulation of fly ash particles with droplets of liquid in Venturi tubes of wet scrubbers of thermal power plants"]. Energotekhnologii $i$ resursosberezhenie [Energy Technologies and Resource Saving]. 2012. No. 2. pp. 44-53. (Rus.)

[7] Volchyn I., Rashchepkin V., Iasynetskyi A. "Flue gas dedusting in Venturi scrubbers at the thermal power plants". Environmental Engineering and Management Journal, 2018, V. 17, No 11. - P. 2515-2525.

[8]. Costa M.A., Ribeiro A.P., Tognetti E.R., Aguiar M.L., Goncalves J.A.S., Coury J.R. "Performance of a Venturi Scrubber in the Removal of Fine Powder from a Confined Gas Stream". Materials Research. 2005.8 (2). pp. 177-179.

[9] Ravi G., Gupta S.K., Viswanathan S., Ray M.B. Optimization of Venturi Scrubbers Using Genetic Algorithm. Ind. Eng. Chem. Res. 2002. 41. pp. 2988-3002.

[10] Evans A.P., Miller C., Pouliot S. "Operational Experience of Commercial, Full Scale Ammonia-Based Wet FGD for Over a Decade", in Proc. Coal-Gen 2009, Charlotte, North Carolina, USA, August 20, 2009. 19 p.

[11] Volchyn I.A., Raschepkin V.A. "Osobennosti ochistki dymovykh gazov v mokrykh skrubberakh s truboi Venturi v usloviyakh povyshennogo orosheniya" ["Specific Issues of Flue Gas Cleaning in Wet Venturi Scrubbers at Excess Spraying"]. Energotekhnologii $i$ resursosberezhenie [Energy Technologies and Resource Saving]. 2018. No. 3. pp. 41-50. (Rus.) 